\title{
Problems of Threats to Russia's Economic Security in Cooperation with the Countries of the Eurasian Economic Union in the Context of Administrative and Legal Regulation
}

\author{
Vladimir F. Gaponenko1, Marina A. Bulgakova ${ }^{2}$, Pavel V. Samolysov ${ }^{3}$, and \\ Vladimir V. Padalka ${ }^{4}$ \\ ${ }^{1}$ Doctor of Economics, Professor, Academy of Management of the Ministry of Internal Affairs of \\ Russia, Moscow, Russia \\ ${ }^{2}$ Candidate of Economics, Senior Lecturer, Academy of Management of the Ministry of Internal \\ Affairs of Russia, Moscow, Russia \\ ${ }^{3}$ Candidate of Pedagogical Sciences, Associate Professor, Academy of Management of the \\ Ministry of Internal Affairs of Russia, Moscow, Russia \\ ${ }^{4}$ Master's Student, Academy of management of the Ministry of Internal Affairs of Russia, Moscow, \\ Russia
}

\section{Abstract}

Corresponding Author: Vladimir F. Gaponenko profgaponenko@gmail.com

Received: 12 March 2019

Accepted: 17 April 2019

Published: 25 April 2019

Publishing services provided by Knowledge E

(c) Vladimir F. Gaponenko et al. This article is distributed under the terms of the commons Attribution License, which permits unrestricted use and redistribution provided that the original author and source are credited.

Selection and Peer-review under the responsibility of the Individual and Society in the Global Era Conference Committee.

\section{G OPEN ACCESS}

The paper examines topical the problems of minimizing threats to Russia's economic security when interacting with the countries of the Eurasian Economic Union in the context of administrative and legal regulation, problems arising in the organization of this work and the direction of their improvement. The objective of the study is to comprehensively study, analyze and summarize the theoretical provisions and results of practical activities in the sphere of minimizing threats to Russia's economic security when interacting with the countries of the Eurasian Economic Union in the context of administrative and legal regulation. Methodology: Approved scientific methods for the comprehensive study of phenomena and processes in their interdependence and, above all, the didactic method of cognition. In the process of collection and processing of empirical material, the author used a comprehensive, systemic, axiological and synergetic approaches that ensure a comprehensive study of the problems of minimizing threats to Russia's economic security when interacting with the countries of the Eurasian Economic Union in the context of administrative and legal regulation. Results: it is necessary to confess that government activity on providing of economic security and defense of national interests of country in area of economy must come true on permanent basis.

Keywords: minimization of threats of economic security to Russia; Eurasian Economic Union; administrative legal regulation; system of theoretical knowledge and practical recommendations of minimization of threats of economic security to Russia at cooperating with the countries of the Eurasian economic union; assistance to development of small and middle enterprise due to the decline of financial and administrative expenses; diagnostics and monitoring of economic strength security. 


\section{Introduction}

In the contemporary geopolitical conditions considering the sanctions imposed on Russia by the USA and European countries, and unstable prices for energy sources, state leaders, various politicians and economists have demonstrated a surge in interest in the Russian economic security [11-14; 16-30]. The state economic security constitutes an integral part of the national security representing one of its main components.

\section{Materials and Methods}

The authors applied proved scientific methods of complex research on events and processes in their interdetermination and, above all, the didactic method. While obtaining and processing the empirical material, the authors employed complex, system, axiological and synergetic approaches that ensure the comprehensiveness of researching the minimization of threats to the Russian economic security provided the cooperation with the Eurasian Economic Union in the field of administrative and legal regulation.

Considering the actions taken by the government in order to protect the Russian national security from the Western sanctions, one elaborated the legal regulation, including the administrative and legal one introduced by the plan of primary measures ensuring sustainable economic development and social stability, so-called the anti-crisis plan, that are, in their essence, to protect the country's economic security [1-12].

\section{Literature Review}

The activity of the state bodies for the economic security protection is thought to be of a permanent character, blend in the formation of the state economic policy rather than a simple response to any geopolitical occurrences.

The term "economic security" emerged in 1934 in the USA when President Roosevelt established a special committee named this way. The committee had to work out the measures to overcome the Great Depression. Having solved the set task, the body's functions were expanded to the national security, with the economic one always being its major component.

The collapse of the USSR and the socialist economic system along with the transition to the market mechanisms required the state activity specialized in ensuring the national and the economic security of Russia. The state bodies had to monitor the economic 
security of the Russian Federation. On March 5, 1992 there were adopted the Law No. 2446-1 "On security" that was further amended many times. Its recent wording was adopted by the State Duma on December 7, 2010 and approved by the Federation Council on December 15, 2010. There was established the Security Council of the Russian Federation with the special administrative body for the economic security. The real activity was developing very slowly. Only in 1994 it was agreed to elaborate the Economic Security Strategy. The elaboration took about 2 years, passed through many discussions and was finally approved in its reduced form in 1996 as the Main Directions. Nevertheless, the Strategy was able to formulate the main concepts in the field such as Russian national economic interests, threats to the economic security, threshold level of the economic security, etc. The approved Economic Security Strategy was designed for 5 years taking the rapidly changing world market into account. It was followed by the period of informational, organizational and methodological maintenance of the monitoring of the state's economic security. In the course of the works, one elaborated and agreed with the federal ministries on the list of the threshold values (indicators) of the Russian economic security, as well as their precise quantitative parameters. It was accomplished by the administrative body for the economic security of the Security Council of the Russian Federation together with The Institute of Economics of the Russian Academy of Science (RAS). Despite the Scientific Council of the Security Council of the Russian Federations's approval, eventually the lists and quantitative parameters were not adopted. They are revised and approved from time to time, and have been implemented only in the scientific materials of the Institute of Economics of RAS. It should be highlighted that the responsibility for the economic security monitoring, elaboration of the necessary measures to protect national interests in the economic area were fixed in the governmental provision on some federal ministries of the economic bloc. There were established subdivisions on the economic security in some ministries. The Russian Ministry of Economics elaborated the section on the economic security in the forecasting reports on socio-economic development almost up to the early XXI century. At that hard time for the country, the Russian president managed to create the prerequisites for the preservation of particular branches being at the verge of collapse. Among them, there was the production of mineral fertilizers, machine tool manufacture, etc. That said, the Russian government had to report the situation in such branches to the President. To some degree, those steps favoured the overcoming of the most difficult period for the state's economy. 


\section{Discussions}

The early XXI century saw the Russian economy developing at a good pace, the issue of the economic security lost its urgency and became secondary.

Given the geopolitical situation arisen in the period of 2014-2017 and related with the Western sanctions and the decrease in the world prices for energy sources affecting the Russian economy, the issue of the national economic security has become the priority again.

From the political and economic point of views, the Eurasian Economic Union (EAEU) was established and has been functioning against the background of competing Russia and the West. Currently, the economic sanctions imposed on Russia by a number of European countries and the USA have a negative impact on the Russian economic security. These conditions encourage the post Soviet countries to establish economic and political unions in order to maintain the main macroeconomic indicators of the CIS. There is no doubt the indicated challenges will affect the plans and steps of this union's development.

After the collapse of the USSR, the Western countries applied all their economic power and political resources to accelerate the elimination of the Russian presence in the post Soviet area [31-50]. Given the globalization, it will mean the irreversible loss of vital geoeconomic and geopolitical area that many generations cared for when 'establishing the power'.

The EAEU was established for the comprehensive modernization, cooperation, to enhance the competitiveness of national economies, to create the conditions for stable development, and to increase the living standards in the member-states [1-11].

\subsection{Members}

Belarus ( January 1, 2015)

- Kazakhstan (January 1, 2015)

- Russia ( January 1, 2015)

- Armenia ( January 2, 2015)

- Kyrgyzstan (May 29, 2015) 


\subsection{Prospective members}

- Tajikistan (the government of Tajikistan expressed its interest to become a member and claimed that it is examining possible consequences for the country's economy).

The role of the Eurasian Economic Union in the Russian economic security system can be both positive and negative.

Assuming all the positive aspects of this organization, the cooperation within the EAEU involves possible threats to the Russian economic security.

In the contemporary geopolitical conditions, the state leaders, various politicians and economists have demonstrated a surge in interest in the Russian economic security.

According to professor Senchagov, new threats to the Russian economic security are still metaphysical, unlike the real ones such as the loss of sovereignty, military aggression, etc. He supposes that in Russia the majority of economic threats and challenges have failed to become the imperative of daily life yet [27: 16-17].

It is though that considering Russia as a part of the Eurasian Economic Union, the threats to the Russian national and economic security can be divided into two groups: internal and external.

\section{Results}

Let us take a closer look at some aspects of the distribution of benefits from the cooperation within the created Eurasian economic area that the member-states enjoy. The Eurasian Economic Union continues the ideas and integration within the custom union. Moreover, it was established based on the existing agreements and legal relations that were improved, expanded and modified to conform with the World Trade Organization (WTO) requirements.

So, what has the Eurasian Economic Union really brought to all the participants of this integration project?

According to the majority of economic experts and analysts, the main 'trophy' gained by all the five member-states of the EAEU is a large-scale market. It is these privileges that all the slightly developed states struggle for. Furthermore, sometimes the struggle goes beyond civilized diplomacy and turns into military conflicts between two or among more states. In this case, the process was without firing a single shot and the result was 
quite impressive. Now the EAEU market exceeds 180 million people. It may grow further since other post Soviet states express their wish to join the EAEU. Among them, there are Tajikistan, Abkhazia, South Ossetia, Pridnestrovie, Syria. The latter claimed its intention to join the Eurasian Economic Union in 2014.

The current member-states of the Union can now sell their goods and services within the EAEU under the most favourable conditions. The reduction in and the abolition of the customs and administrative barriers have cut down the transportation expenditures, the cost of goods and services and made the goods more competitive in the memberstates. Given that similar goods and services exported from outside the EAEU cost more at least due to the customs duties.

Indeed, one should not fail to consider the existing objective process of the world economic crisis. It is already clear that under the contemporary geopolitical and geoeconomic conditions make some global markets fall into regional ones. The establishment of the Eurasian Economic Union is a king of an 'economic airbag', an arrangement for the future. If it fails to establish its own macro market, it will end up torn by the European Union and the USA and turn into the aggregate of the unwanted peripheral market. This is what has already happened to Ukraine that completely lost its sovereignty.

Many economists and political analysts believe that the EAEU is a true salvation for all its member-states against the background of the global reconstruction of the world order and world economy [13-14; 18-19; 21-26; 29-30]. The USA is obvious to be losing its leading role and the world is gradually turning from so-called unipolar to multipolar. The world life centres are moving to the East, to Asia and the states able to rapidly develop a new strategy of the integration with neighboring countries and take profitable position will win. This is the way that the EAEU member-states currently follow. The only thing left is to clarify what the states have to offer to one another.

It is thought that in order to minimize threats to the Russian economic security in the context of the EAEU the following is necessary:

- to pay attention to the foreign experience of the integration into various economic unions;

- to search for new forms of cooperation with a certain state of the post-soviet area and, if necessary, with a certain regions (the southeast Ukraine: the Donetsk People's Republic and the Luhansk People's Republic, certain regions of Moldova: Gagauzia, etc.);

- to actively establish free trade zones with other countries; 
- to coordinate the monetary policy of the EAEU member-states;

- to create favourable climate for financial investments to the Russian economy (administrative, fiscal, financial legislation);

- to elaborate a roadmap with precise measure to socialize and integrate foreign citizens into the current Russian economy with the account of Russian people's interests;

- to establish a new law enforcement body - the Eurasian police;

- to consolidate (technically equip) borders with the neighboring countries, including those of the EAEU.

Based on the organizational support one shall do the following:

- the Ministry of Economic Development of the Russian Federation along with the scientific community should make and officially approve the list of indicators reflecting the level of the Russian economic security. According to professor V.K. Senchagov, it must be quite a long list including 100-120 indicators [28: 16];

- one should define the methods to use this list of indicators. It is viable to implement the method of comparing the current indicators with those of some earlier periods or, perhaps, the predicted indicators for the years to come. Besides, if necessary, one can apply foresight, analogue method, etc.;

- all the threats to the economic security should be ranged into groups according to the negative consequences they might bring and the terms to come;

- it is essential to design a new economic security strategy. The current Economic Security Strategy that dates to 1996 has become obsolete. The new strategy should contain the specification of the current state of affairs and define the principal measures that address the assurance of the state's economic security in the mid- and long-term;

- The monitoring of the economic security level and the development of measures for its maintenance should be captured in the regulations of the federal ministries as their duties. In the prognosis reports, there should be a section specifying the current state of the Russian economic security;

- the office for economic security in the Security Council of the Russian Federation should be restored, etc. 


\section{Conclusion}

Thus, one should admit that the state activity on ensuring the economic security and protecting the country's national economic interests should be executed on the permanent basis. The geopolitical situation can change, foreign states can impose or abolish their sanctions, the prices for energy sources can increase and then fall again. It is vital to not only respond to every attack but also ensure that the Russian economy is able to withstand any future both internal and external challenges.

To a large degree, the integration of the post Soviet states depends on the Russian positions. In order to succeed in playing the integrating role within the economic and strategic union, the Russian Federation should become a true leader in the sub regional cooperation, which corresponds to its economic potential, rather than blindly follow the neoliberal premises. The principal criterion for providing economic and financial assistance to weaker partners should be gaining the desirable economic and geopolitical outcomes considering the economic security consolidation in the context of the administrative and legal regulation.

\section{Acknowledgements}

The authors are grateful to study was carried out with the financial support of the Russian Foundation for Basic Research of the Russian Academy of Sciences in the framework of Project No. 18-010-01061/19 on the topic: "Modeling of the strategy of innovative development and import substitution of the oil and gas complex of Russia in the context of economic security».

\section{References}

[1] The Constitution of Armenia: adopted at the referendum on July 5, 1995 (revised and amended on December 6, 2015). Entsiklopediya Krugosvet.

[2] The Constitution of the Republic of Belarus: adopted at the $13^{\text {th }}$ session of the Supreme Council of Belarus on March 15, 1994 (revised and amended on November 24, 1996 and October 17, 2004). National register of the legal acts of the Republic of Belarus. 1999. No.

[3] The Constitution of the Republic of Kazakhstan: adopted at the referendum on August 30, 1995 (revised and amended on October 7, 2007 and February 2, 2011). 
The laws of the Republic of Kazakhstan. 2013.

[4] The constitution of Kyrgyzstan: adopted at the referendum on June 27, 2010. Newspaper "Erkin Too". June 6, 2010. No. 6.

[5] The Constitution of the Russian Federation: adopted by national voting on December 12, 1993 (with revised and amended Federal Constitution Laws (FCL), December 30, 2008 No. 6-FCL, December 30, 2008 No. 7-FCL. Rossiiskaya Gazeta. January 21, 2009. No. 7.

[6] The agreement to establish the Commonwealth of Independent States (CIS) (signed on December 8, 1991. Ratified by the Supreme Council on December 12, 2001. No. 2014-1.

[7] The treaty on the enhancement of economic and humanitarian integration. March 29, 1996.

[8] The treaty on the Eurasian Economic Community. October 10, 2000. (revised on January 25, 2006 and October 6, 2007).

[9] The treaty on single customs territory and customs union. (signed on October 6 , 2007).

[10] The declaration on Eurasian economic integration. November 8, 2011.

[11] The treaty on Eurasian Economic Union. (signed in Astana on May 29, 2014) (revised on May 8, 2015).

[12] The Edict of the President of the Russian Federation on the Russian Strategy for national security 2030, December 31, 2015. No. 683.Rossiiskaya Gazeta. December 31, 2015.

[13] Bagdasarov, S.A. (2015). On the expansion of the SCO and the EAEU, the ISIL, the power of Rahmon and Karimov... Independent Newspaper 'Grazhdanin-Sozidatel Segodnya'.

[14] Baranovsky, V.G. (2018). Foreign policy resources of the Russian modernization. Moscow: IMEMO RAS.

[15] Brzezinski, Z. (2010). The Grand Chessboard: American Primacy and Its Geostrategic Imperatives. Moscow: Mezhdunarodnye Otnosheniya.

[16] Gaponenko, V.F. (2008). The priority model for managing financial resources of small and medium business based on the value-oriented approach in the context of the economic security. Mikroekonomika, 1: 55-62.

[17] Gaponenko, V.F., Alaberdeev, R.R. (2017). Issues of administrative and legal regulation of ensuring the economic security of the Russian oil and gas complex entities. The Proceedings of the Armenian Ministry of Domestic Affairs, 4 (44): 32-35. 
[18] Gaponenko, V.F., Padalka, V.V. (2015). The Russian economic security assurance in the context of the Eurasian Economic Union. In Proceedings of VIII international scientific and practical conference "Mechanisms of economic and legal assurance of the national security: experience, problems, prospects". Krasnodar: Publishing House YulM. P. 86-94.

[19] Gaponenko, V.F., Padalka, V.V. (2015). Do one need the Eurasian police (Euraspol) for the common economic space within the Eurasia Economic Union? Vestnik Moskovskogo universiteta Ministerstva vnutrennikh del Rossii. 12(1): 253-258.

[20] Gaponenko, V.F., Palishkina, O.V. Палишкина (2016). Assuring the economic security in the fiscal field. Moscow: Academy of Management of the Ministry of Internal Affairs of Russia.

[21] Ziyadullaev, N.S. (2015). The formation of the Eurasian Economic Union: risks and chances during the turbulence. Rossiiskii vneshneeconomicheskiy vestnik. 5: 3-18.

[22] Zolotova, L.V., Lapteva, E.V., Portnova, L.V. (2017). The methods of modeling and predicting economy. Orenburg: OOO "IPK Universitet".

[23] Kashkina, I.V. (2018). Contemporary international security system. Moscow: NestorIstoriya.

[24] Kuznetsova, E.I., Gamonenko, S.S. (2015). Financial monitoring as a control method in managing the economic security. Vestnik Moskovskogo universiteta Ministerstva vnutrennikh del, 1: 185-189.

[25] Moiseev, E.G. (2018). International legal basis for the Eurasian Economic Union's establishment and function. Moscow: Prospekt.

[26] Putin, V.V. (2011). New integration project for Eurasia - the future emerges today. Izvestiya, November 3.

[27] Senchagov, V.K. (2015). Russian budget. In Developing and ensuring economic security. Moscow: Infra-M. P. 16-17.

[28] Senchagov, V.K., Ivanova, E.A. (2015). Mechanism structure of the contemporary Russian economic security: report. Moscow.

[29] Shakleina, T.A., Baikov, A.A. (2018). Megatrends: the main directions of the world order evolution in the XXI century. Moscow: Aspekt Press.

[30] Yaremenko, Yu. V. (2015). Contemporary Russian economy: development analysis and strategy. Problemy prognozirovaniya, May 5: 3-10.

[31] Bradley, J., Postel-Vinay, F., Turon, H. (2016). Public Sector Wage Policy and Labor Market Equilibrium: A Structural Model. Journal of the European Economic Association. 14: 2-41. 
[32] Achkasov, Yu.K., Pilnik, N.P. (2017). Income Tax Effect on Economic Performance in Terms of Endogenous Choice between Labor and Enterprise Market. Journal of the New Economic Association, 1(33): 12-27.

[33] Bradley, J., Postel-Vinay, F., Turon, H. (2016). Public Sector Wage Policy and Labor Market Equilibrium: A Structural Model. Journal of the European Economic Association, 14. P. 2-41.

[34] Pugliese, E., Chiarotti, G.L., Zaccaria, A., Pietronero, L. (2017). Complex Economies Have a Lateral Escape from the Poverty Trap. PLoS ONE. 12(1): 1-18.

[35] Soo, K.T. (2016). Intra-Industry Trade: A Krugman-Ricardo Model and Data. Economica. 83(330): 338-355.

[36] Batten, D. (2017). Complex landscapes of spatial interaction. The Annals of Regional Science. 35.

[37] Bank Secrecy Act (BSA) (also called the Currency and Foreign Transactions Reporting Act), Pub. L. No. 91-5081 (2016), codified at 12 U.S.C. §\$1829b and 195159, and 31 U.S.C. §§ 5311-5330; see also 31 C.F.R. §103.

[38] Canada's Atlantic Gateway. (2014). Publishing House "Canada’s Atlantic Gateway”.

[39] Van Veldhoven, G. (2018). Dynamic aspects of economic behavior: some determinants. In Handbook of economic psychology. L. Dodrecht.

[40] Zywicki, T.J. (2018). "Bankruptcy". In Henderson, D.R. (Eds.). Concise Encyclopedia of Economics (2nd ed.). Indianapolis: Library of Economics and Liberty.

[41] Foellmi, R., Zweimüller, J. (2004). Inequality, Market Power, and Product Diversity. Economics Letters. 820: 139-145.

[42] Helpman, E. (2004). The Mystery of Economic Growth. Cambridge: Belknap by Harvard University Press. Helpman E., Itskhoki O., Redding S. (2008). Wages, Unemployment and Inequality with Heterogeneous Firms and Workers. NBER Working Paper No. 14122.

[43] Jones, R.W. (1965). The Structure of Simple General Equilibrium Models. Journal of Political Economy. 730(6): 557-572.

[44] Katz, L.F., Murphy, K.M. (1992). Changes in Relative Wages, 1963-1987: Supply and Demand Factors. The Quarterly Journal of Economics. 1070(1): 35-78.

[45] Krugman, P. (1991). Increasing Returns and Economic Geography. Journal of Political Economy. 99(3): 483-499.

[46] Krusell, P., Smith, J., Anthony, A. (1998). Income and Wealth Heterogeneity in the Macroeconomy. Journal of Political Economy. 1060(5): 867-896. 
[47] Kumar, A., Schuetze, H.J. (2007). Self-Employment and Labor Market Policies. University of Victoria, Department of Economics, Discussion Paper DDP0704. Lee, D.S. (1999). Wage Inequality in the United States During the 1980s: Rising Dispersion or Falling Minimum Wage? Quarterly Journal of Economics. 112: 977-1023.

[48] Leonardi, M. (2003). Product Demand Shifts and Wage Inequality. Retrieved from http://citeseerx.ist.psu.edu/viewdoc/download?doi=10.1.1.527.700

[49] Okun, A. (1975). Equality and Efficiency: The Big Tradeoff. Washington: The Brookings Institution. Pissarides, C. (2000). Equilibrium Unemployment Theory. Cambridge: MIT Press. Shapiro, C., Stiglitz, J.E. (1984). Equilibrium Unemployment as a Worker Discipline Device. The American Economic Review. 740(3): 433-444.

[50] Stole, L.A., Zwiebel, J. (1996). Organizational Design and Technology Choice under Intrafirm Bargaining. The American Economic Review. 860(1): 195-222. 